Prof. dr. Safvet Halilović ${ }^{1}$

\title{
KIRAETI I NJIHOV ZNAČAJ U TEFSIRSKOJ NAUCI
}

\section{SAŽETAK}

Jedna od specifičnosti kur'anskog teksta je i mogućnost da se pojedine riječi Kur'ana časnog, shodno samoj Objavi, mogu izgovarati na više načina. U vezu s tim u islamskoj tradiciji, postoji posebna naučna disciplina koja se zove kiraeti ('ilm al-qira'at). To je nauka koja se bavi izučavanjem izgovora kur'anskih riječi, koje se prenose od Allahovog Poslanika, s.a.v.s. U toj naučnoj oblasti postoje autoriteti, koji su postavili precizne kriterije $i$ napisali ogromnu literaturu, sve u cilju očuvanja autentičnosti kur'anskog teksta.

U ovome radu, nakon kratkog historijskog osvrta o nastanku nauke o kiraetu, gdje su spomenuti glavni predstavnici $i$ njihova naučna metodologija, razmatrat ćemo mjesto i značaj kiraeta $u$ tefsirskoj nauci koja se, prije svega, bavi izučavanjem Kur'ana časnog u cilju otkrivanja onoga značenja koje Uzvišeni Stvoritelj želi reći ljudima. U tom pogledu, kiraeti zauzimaju veoma značajno mjesto u sklopu tefsirske nauke, pogotovo ako se ima u vidu da različito izgovaranje pojedinih kur'anskih riječi može imati posljedicom drugačije propise i značenje kur'anskoga teksta.

U radu smo ukazali na ogroman trud koji su komentatori Kur'ana uložili u svojim tefsirskim djelima baveći se analizama kiraeta $i$ utvrđivanjem njihove autentičnosti (ithbat tawatur alqira'at), naročito pravilnim usmjeravanjem svakog validnog kiraeta $i$ detaljnim objašnjenjem značenja koje on u sebi sadrži.

Ovaj rad, između ostalog, ukazuje na to da mogućnost izgovaranja pojedinih riječi Kur'ana na više načina govori, zapravo, o veličini i univerzalnosti kur'anskoga teksta. Kur'an je Božiji govor, njegova značenja su neiscrpna $i$ ne mogu biti svedena na neku, vremenom ograničenu dimenziju ljudskoga shvatanja.

U pisanju ovoga rada korištena je, uglavnom, historijskoanalitička metoda.

\footnotetext{
${ }^{1}$ Islamski pedagoški fakultet u Zenici
} 
Ključne riječi: Al-Džassas, autentični (mutevatir) kiraeti, Ibn alDžazari, kiraeti, šadzdz (neautentični) kiraeti, sedam kiraeta, tefsir. Uvod o nastanku nauke o kiraetima

\section{Uvod o nastanku nauke o kiraetima}

Kur'an časni je, prema temeljnome islamskome učenju, Allahova Riječ, objavljena vjerovjesniku Muhammedu, s.a.v.s., da je prenese ljudima na arapskome jeziku. Kur'an je vječni Allahov Govor, kako po značenju tako i po svome slovu i zvuku. To je Božija Knjiga koja je objavljena vjerovjesniku Muhammedu, s.a.v.s., i on je posljednja objava Gospodara svjetova ljudskome rodu.

Kur'an nije ni prozno ni poetsko djelo i nema načina da se on klasificira u bilo koji književni rod ili vrstu. Kao što je Allah Uzvišeni u Kur'anu časnom za Sebe rekao da mu ništa nije slično (Laysa kamithlihi šay'un, Aššsura: 11), tako ni Njegovoj Knjizi nijedna druga ljudska usmena ili pisana tvorevina nije slična. ${ }^{2}$

Kur'anski izraz je natopljen snagom Božanske Riječi; otud veličanstvenost njegovih poruka i njegovoga stila, koji nije ni stih ni proza. Stoga on i jeste najveći fenomen (mudžiza) Allahovoga Poslanika, s.a.v.s., i glavni izvor islama. Iz njegovih savršenih načela milioni muslimana, širom zemaljske kugle, stoljećima crpe snagu za ostvarenje plemenitih ciljeva ovoga i budućega svijeta.

Jedna je od specifičnosti kur'anskog teksta i mogućnost da se pojedine riječi Kur'ana časnog, shodno samoj Objavi, mogu izgovarati na više načina. U vezu s tim u islamskoj tradiciji postoji posebna naučna disciplina koja se zove kiraeti ('ilm al-qira'at). To je nauka koja se bavi izučavanjem izgovora kur'anskih riječi, koje se prenose od Allahovog Poslanika, s.a.v.s. U toj naučnoj oblasti postoje autoriteti koji su postavili precizne kriterije i napisali ogromnu literaturu, na što ćemo se ukratko osvrnuti u ovome uvodu.

Istaknuti islamski učenjak iz područja kur'anskih znanosti Ibn al-Džazari ${ }^{3}$ kiraet definiše kao nauku o načinu artikulisanja kur'anskih

${ }^{2}$ Džemaludin Latić, Kur'an - proljeće srca tvog, Novi muallim, br. 18, str. 18 .
${ }^{3}$ Muhammad ibn Muhammad ibn Yusuf, Abu al-Khayr ad-Dimišqi aš-Šafi'i, poznat
kao Ibn al-Džazari (751-833. H.), veliki je autoritet u području kiraeta (čitanja)
Kur'ana. Napisao je brojna djela u tom području, od kojih su najpoznatija: An-Našr 
riječi u njihovim različitim formama, shodno predajama poznatih autoriteta iz te oblasti. Drugim riječima, to je nauka koja se bavi načinima izgovaranja riječi Kur'ana časnog, s obzirom na to da postoji više vidova izgovaranja pojedinih riječi, koje se prenose isključivo od Allahovog Poslanika, s.a.v.s. ${ }^{4}$

Učenjaci su iznijeli načelo na osnovu kojega se prepoznaju pouzdani kiraeti (al-qira'at as-sahiha al-mutawatira) od neautentičnih i neprihvatljivih (al-qira'at aš-šadhdha al-marduda). U tom smislu kažu: Svako čitanje (kiraet) saglasno $\mathrm{s}$ arapskim jezikom i jednim od primjeraka Osmanovog mushafa, ukoliko je potvrđeno mutevatir (mutawatir) predajom, čitanje je koje treba prihvatiti, koje se ne može osporavati i odbiti. Ono je jedno iz skupine sedam harfova (sab'a ahruf) na kojima je objavljen Kur'an časni. Ukoliko nije ispunjen samo jedan ili svi uvjeti u nekom čitanju, ono je neprihvatljivo. Potrebno je znati da je najvažniji treći uvjet, a prethodna dva se podrazumijevaju, jer, ukoliko je lanac predaje mutevatir, čitanje je samim tim saglasno $\mathrm{s}$ arapskim jezikom $\mathrm{i}$ jednim od primjeraka Osmanovog mushafa. ${ }^{5}$

Naziv sedam kiraeta (al-qira'at as-sab'a) nije bio poznat u islamskim pokrajinama u vrijeme pisanja prvih radova iz ove oblasti. Prvi učenjaci koji su o tome pisali, kao što su npr. Abu- 'Ubayda alQasim ibn Sallam, Ibn-Džarir at-Tabari, Abu-Hatim as-Sidžistani i dr., u svojim radovima spominju više od sedam kiraeta. Naziv sedam kiraeta počeo se upotrebljavati krajem II stoljeća po Hidžri, tako što su ljudi u različitim krajevima prihvatali određeni kiraet koji se dovodio u vezu s nekim od istaknutih karija (učača). Tada su u muslimanskim pokrajinama bili rašireni sljedeći kiraeti: u Mekki je

fi al-qira'at al-'ašr, Taqrib al-Našr, Tabaqat al-qurra' i dr. (Vidjeti: Az-Zirikli, AlA'lam, tom VII, str. 45.)

${ }^{4}$ Muhammad az-Zuhayli, Ta'rif'amm bi al-'ulum aš-šari'a, str. 27.

5 'Abd al-Fattah al-Qadi, Al-Qira'at aš-šadhdha wa tawdžihuha min luga al-'Arab, str. 7. Isti rad postoji i kao suplement djelu istoga autora Al-Budur az-zahira fi alqira'at al-'ašra al-mutawatira min tariqay aš-Šatibiyya wa ad-Durra. Autor o ova tri uvjeta piše opširno, na nekoliko stranica. Rukovodeći se načelom da ne oduljimo, ovdje samo ukazujemo na ovu važnu literaturu. (Vidjeti: Al-Qira'at šl-šadhdha..., str. 7-10.) 
bio poznat Ibn-Kathirov, ${ }^{6}$ u Medini Nafi'ov, ${ }^{7}$ u Siriji Ibn- 'Amirov, ${ }^{8} \mathrm{u}$ Basri Abu-'Amrov, ${ }^{9}$ u Kufi Hamzin, ${ }^{10}$ Asimov $^{11}$ i Al-Kisa'ijev ${ }^{12}$ kiraet.

Krajem III hidžretskog stoljeća Ibn-Mudžahid ${ }^{13}$ je sabrao kiraete sedam navedenih autoriteta. Njihovi kiraeti su, nakon toga, stekli

6 'Abdullah ibn Kathir ad-Dari al-Makki (umro 120. H./737.), kadija u Mekki. Iz reda ashaba susreo se s Anasom ibn Malikom, 'Abdullahom ibn az-Zubayrom, Abu Ayyubom al-Ansarijem i od njih učio kiraet. (Vidjeti: Ibn al-Džazari, Tabaqat alqurra', I, str. 443; Az-Zirikli, Al-A'lam, IV, str. 115.)

Nafi' ibn 'Abd ar-Rahman ibn Abu-Nu'aym al-Madani (umro 169. H./785.), kiraet učio od sedamdeset tabi'ina, koji su učili od Ubayya ibn Ka'ba, Ibn-'Abbasa i AbuHurayre. Za njega se kaže da je sedamdeset godina bio najbolji znalac u području kiraeta. (Vidjeti: Tabaqat al-qurra', II, str. 330-334; Al-A'lam, VIII, str. 5.)

8 'Abdullah ibn 'Amir ibn Yazid, Abu-'Imran al-Yahsabi aš-Šami, poznat kao Ibn'Amir (umro 118. H./735). Kiraet je učio od Mugire ibn Abu-Šihaba, koji je učio od Osmana ibn 'Affana. Iz reda ashaba se susretao s Nu'manom ibn al-Baširom i Walilom ibn al-Asqa'om. Neki tvrde da se susretao i s Osmanom 'Affanom i neposredno od njega učio. Bio je kadija u Damasku za vladavine Walida ibn 'Abd al-Malika. Hafiz adh-Dhahabi za njega kaže: Učitelj Sirijaca u kiraetu, pouzdan prenosilac hadisa. (Vidjeti: Tabaqat al-qurra', I, str. 423-425; Al-A'lam, IV, str. 95.) ${ }^{9}$ Zabban ibn 'Ammar at-Tamimi al-Basri, zvani Abu al-'Ala', dakle Abu 'Amr ibn al'Ala' al-Basri (70. H./689-154.H./770.), veoma istaknut jezikoslovac i pisac. Kiraet je učio od Mudžahida ibn Džabra, Sa'ida ibn Džubayra, koji su učili od 'Abdullaha ibn 'Abbasa i Ubayya ibn Ka'ba. Abu-'Ubayda tvrdi: Bio je najobrazovaniji jezikoslovac, pisac, znalac Kur'ana i pjesništva. (Vidjeti: Tabaqat al-qurra', I, str. 228-292; Al-A'lam, III, str. 41.)

10 Hamza ibn Habib ibn 'Umara al-Kufi az-Zayyat (80 .H./699-156. H./722). Prilikom učenja kiraeta oslanjao se na konsenzus (iď̌ma'). Veliki islamski učenjak Sufyan at-Thawri za njega je rekao: Hamza ni slova nije pročitao izvan okvira predaje. Učio je od Al-A'maša, koji je učio od Yahye ibn Wathaba, Zerra ibn Hubayša i 'Abdullaha ibn Mas'uda. (Vidjeti: Tabaqat al-qurra', I, str. 261-263; Al-A lam, II, str. 277.)

11 'Asim ibn Abu an-Nadžud al-Asadi al-Kufi (umro 127.H./744.), jedan od sedemerice poznatih karija (učača), ubraja se među tabi'ine. Kiraet učio od Zerra ibn Hubayša koji je učio od 'Abdullaha ibn Mas'uda. Njegov kiraet je danas najrasprostranjeniji. Hafiz ad-Dhahabi za njega tvrdi: Veliki je autoritet u kiraetu a, isto tako, i u hadisu. (Vidjeti: Tabaqat al-qurra', I, str. 346-349; Al-A'lam, III, str. 248; Tahdhib at-tahdhib, V, str. 38; Mizan al-i'tidal, II, str. 5.)

12 'Ali ibn Hamza al-Asadi al-Kufi (umro 189.H./804.), istaknuti autoritet, predvodnik u jezikoslovlju, gramatici i kiraetu. Bio je odgajatelj halife Haruna arRašida i njegovoga sina Al-Amina. Autor je djela: Ma'ani al-Qur'an, Al-Qira'at, AnNawadir, Mukhtasar fi an-nahw, Al-Mutašabih fi al-Qur'an i drugih. (Vidjeti: AlA'lam, IV, str, 283.) 
veliku popularnost, dotle da su mnogi pomišljali kako sedam kiraeta znače sedam harfova spomenutih u Poslanikovom, s.a.v.s., hadisu: Kur'an je objavljen na sedam harfova (slova, narječja). ${ }^{14}$ Pošto je IbnMudžahidov zbir i brojčana saglasnost sa spomenutim harfovima proizvod slučajnosti, tim prije što je među autoritetima kiraeta bio znatan broj onih koji nisu bili manje važni od sedam sabranih, ${ }^{15}$ neki učenjaci Ibn- Mudžahidu prigovaraju to što je kiraete sveo na broj koji se dovodi u vezu sa sedam harfova spomenutih u hadisu. ${ }^{16}$

Međutim, istina je da postoji kriterij koji, ako je ispunjen $\mathrm{u}$ nekom čitanju, takvo čitanje potvrđuje kao prihvatljivo. S obzirom na to, prema nekim autoritetima, ima deset, a po drugim četrnaest prihvatljivih kiraeta. $^{17}$

Kada je riječ o zbiru od deset kiraeta, on podrazumijeva sedam čuvenih, kojima se pridodaju: Ya'qubov, ${ }^{18}$ Khalafov $^{19}$ i Abu-

13 Abu-Bakr Ahmad ibn Musa ibn al-'Abbas at-Tamimi al-Bagdadi, poznat kao IbnMudžahid (245. H./859-324.H./935.), veliki poznavalac kiraeta u svoje vrijeme. Napisao: Kitab al-Qira'at al-kabir, Al-Sab'a fi al-Qira'at (štampano uz kritičku obradu Šawqija Dayfa). Vidjeti: Tabaqat al-qurra', I, str. 39; Al-A'lam, I, str. 261.

${ }^{14}$ Hadis je muttafaq 'alayh; prenose ga Al-Bukhari (As-Sahih, Kitab: Al-Khusumat, br. 2.241., Kitab: Fada'il al-Qur'an, br. 4.608-4.609., Kitab: At-Tawhid, 6.995.) i Muslim (As-Sahih, Kitab: Sala al-musafirin, br. 1.354., 1.356-1.357. u sklopu hadisa: Ovaj Kur'an je objavljen na sedam harfova...).

${ }^{15}$ Vidjeti: Az-Zarakaši, Al-Burhan..., I, str. 329.

${ }^{16} \mathrm{O}$ tome Abu al-'Abbas Ahmad ibn 'Umara, autoritet u kiraetu i mufessir (umro 430. H./1038.), kaže: Svođenje na broj 'sedam' proizvelo je nešto sasvim nepotrebno. Uopćeno uzevši, najosjetljivije je to što svako ko to površno gleda pomišlja da se radi o 'sedam harfova', da se sedam 'čitanja' podudara sa sedam narječja spomenutih u predaji. Kamo sreće da je zbir za makar jedan manji ili veći od sedam. Sumnja bi time bila otklonjena. (Vidjeti: Al-Itqan, izdanje Al-Hidžazi, Kairo, 1360. H., I, str. 138.)

${ }^{17}$ Vidjeti: Subhi as-Salih, o. c., str. 249; 'Abd al-Fattah al-Qadi, Al-Budur az-zahira fi al-qira'at al-'ašr al-mutawatira, str. 7-10.

${ }^{18}$ Ya'qub ibn Ishaq ibn Zayd al-Hadrami (117. H./735-205. H./820.), rođen i umro u Basri. Autor je brojnih radova, a poznato mu je djelo Al-Džami', za koje Az-Zubaydi kaže: U njemu ja sabrao sve što se ogleda kroz razlike u kiraetima, pripisujući svaki specifičan primjer onome kome pripada. (Vidjeti: Al-A'lam, VIII, str. 195.)

${ }^{19}$ Khalaf ibn Hišam al-Bazzar al-Asadi (umro 229. H./843.), Više vidjeti: Tabaqat al-qurra', I, str. 272; Al-A'lam, II, str. 311. 
Dža'farov ${ }^{20}$ kiraet, a četrnaest kiraeta obuhvata ovih deset i još četiri, a to su: kiraet Al-Hasana al-Basrija, ${ }^{21}$ Ibn-Muhaysina, ${ }^{22}$ Yahye alYazidija $^{23}$ i Al-A'maša. ${ }^{24}$

Potrebno je istaći da među temeljne uvjete prihvatljivosti nekog kiraeta/čitanja spada povezanost lanca predaje i prenošenje putem usmenog preuzimanja, dakle slušanja uživo. Zato s pravom treba primijetiti da je ono što ima značaj u pouzdanosti kod protagonista hadiske nauke jednako važno i prilikom utvrđivanja lanca kod kiraeta. Kao što su učenjaci izvlačili zakonske propise i osnove za komentar kur'anskih sadržaja iz predaja s pouzdanim lancima, tako ni kiraet nekog karije (čitača, učača) nije mogao biti prihvaćen ako nije bilo pouzdano utvrđeno od koga je usmeno (tj. slušanjem uživo) preuzeto, dok se ne potvrdi da je lanac neprekinut sve do ashaba koji je takav kiraet preuzeo od Allahovog Poslanika, s.a.v.s. ${ }^{25}$

Potpune povezanosti lanca preko kojega je određeni kiraet prenesen, podstaknula je istraživače da kiraet kvalificiraju kao ono što je utvrđeno Objavom, pa su radi toga apsolutno zabranili kiraet po analogiji (qiyas) odbacivši stavove onih koji su tvrdili da su kiraeti

${ }^{20}$ Yazid ibn al-Qa'qa' al-Makhzumi, poznat kao Abu-Dža'far (umro 132. H./749.), bio je jedan od najvećih autoriteta kiraeta u Medini. (Vidjeti: Tabaqat al-qurra', II, str. 382; Al-A'lam, VIII, str. 186.)

${ }^{21} \mathrm{Al}-\mathrm{Hasan}$ ibn Yasar al-Basri - poznati učenjak iz generacije tabiina.

${ }^{22}$ Muhammad ibn 'Abd ar-Rahman as-Sahmi, poznat kao Ibn-Muhaysin (umro 123. H./740.), autoritet kiraeta u Mekki, nasljednik Ibn-Kathira. Zasnovao je kiraet koji je sadržavao izvjesna odstupanja od Mushafa. Neki su ga zbog toga odbacili odbijajući da ga ubroje među mutevatir kiraete. Bio je dobar poznavalac hadisa. (Vidjeti: Tahdhib at-tahdhib, VII, str. 474, Al-A'lam, VI, str. 189; 'Abd al-Fattah alQadi, o. c., str. 11-12.)

${ }^{23}$ Yahya ibn al-Mubarak al-Yazidi (umro 202. H./717.), jezikoslovac i pisac iz Basre. Kiraet je učio pred čuvenim autoritetima Abu-'Amrom i Hamzom. Živio je u Bagdadu i odgajao Al-Ma'muna, sina čuvog halife Haruna ar-Rašida. Autor je nekoliko radova iz područja jezikoslovlja i gramatike. (Vidjeti: Al-A'lam, VIII, str. 163; 'Abd al-Fattah al-Qadi, o. c., str. 14.)

${ }^{24}$ Sulayman ibn Mahran Al-A'maš al-Asadi al-Kufi (umro 148. H./765.), kiraet je učio od Ibrahima an-Nakhaija, Zarra ibn Hubayša, 'Asima, Mudžahida i drugih. Bio je pobožan, skroman i veoma obrazovan u oblasti kiraeta. Ubrajao se među hafize hadisa. (Vidjeti: 'Abd al-Fattah al-Qadi, o. c., str. 16-17.)

${ }^{25}$ U djelu At-Taysir fi al-qira'at as-sab'a, Abu-'Umara ad-Danija (str. 8. i dalje) postoji precizan opis lanaca sedam učača (karija), iz kojih se jasno vidi do koje mjere su učenjaci vodili računa o pouzdanosti predaja i utvrđivanja slušanja uživo. 
stvar izbora, da se uzimaju u ovisnosti o izboru rječitih ljudi i rješenja koja nude dobri stilističari. Zato su decidno istaknuli, kako se ono što nije suglasno $\mathrm{s}$ arapskim jezikom i sa jednim od primjeraka Osmanovoga mushafa, i nije preneseno pouzdanim lancem predaje, istim kao kad se radi o lancu prenosilaca hadisa, ne prihvata kao validan kiraet. $^{26}$

Radi raspoznavanja pouzdanih i prihvatljivih kiraeta (al-qira'at al-sahiha al-maqbula) od neprihvatljivih (al-qira'at aš-šadhdha almarduda), učenjaci su, kao što je na početku rada već isticano, postavili kriterij prihvatljivosti. On se sastoji iz tri uvjeta:

1. suglasnost s jednim od primjeraka Osmanovog mushafa,

2. suglasnost $\mathrm{s}$ arapskim jezikom, $\mathrm{i}$

3. pouzdanost lanca predaje putem kojega je prenesen određeni kiraet.

U djelu Mundžid al-muqri'in Ibn al-Džazari ističe da uvjet pouzdanost lanca predaje znači da je takvo čitanje (kiraet) preneseno velikim brojem prenosilaca (tawatur), jer da bi nešto bilo Kur'an ( $\mathrm{tj}$. imalo tretman Kur'ana), mora biti preneseno mutevatir predajom. Prema tome, kiraeti pridodati iznad zbira od deset smatraju se da su s pouzdanim lancima, ali im pouzdanost počiva na kazivanjima pojedinaca koja nemaju status mutevatir predaje. Konsekventno tome, takvi kiraeti ne mogu biti izrijeci koji se koriste u ibadetu. Preciznije rečeno, takve kiraete nije dozvoljeno koristiti prilikom obavljanja namaza. $^{27}$ Mutevatir kiraeti (al-qira'at al-mutewatira), koje je muslimanska zajednica prihvatila, jesu deset kiraeta (al-qira'at al'ašr $r$ ) koje su nasljednici preuzimali od prethodnika prenoseći ih tako sve do nas, tako da danas, mimo ovih deset, ne postoje drugi mutevatir kiraeti. $^{28}$

\section{Kiraeti i tefsir}

Postoje brojne definicije kojima su islamski učenjaci pokušali da definiraju tefsirsku nauku. $U$ jednoj od tih definicija ističe se da je

\footnotetext{
${ }^{26}$ Vidjeti: Subhi as-Salih, o. c., str. 250-251. Tu su izneseni primjeri neprihvaćenih kiraeta (al-qira'at al-marduda).

${ }^{27}$ Vidjeti: Abu al-Qasim an-Nuwayri, Muqaddima li šarh Tayba al-Našr fi qira'at al-'ašr, str. 73-78.

${ }^{28}$ Vidjeti: Subhi as-Salih, op. cit. str. 255-256; 'Abd al-Fattah al-Qadi, o. c., str. 9.
} 
tefsir nauka koja proučava Kur'an časni u cilju otkrivanja onoga značenja koje Allah, dž. š., želi iskazati u Svojoj Knjizi; sve to u okvirima ljudskih mogućnosti $i$ nakon ispunjenja svih uvjeta $i$ pretpostavki koje su potrebne da bi se neko mogao baviti komentarisanjem Škur'ana. ${ }^{29} \mathrm{U}$ sklopu tih uvjeta navodi se i obavezno poznavanje kiraeta (čitanja) Kur'ana časnog.

Istaknuti učenjak iz muslimanske Španije Abu-Hayyan alAndalusi (umro 745. H./1344.) kaže da je tefsir nauka u sklopu koje se izučava način izgovaranja kur'anskih riječi, njegove poruke, propise, pojedinačna i kontekstualna značenja koja im određuje specifična upotreba i druga prateća pitanja ${ }^{30}$, a čuveni alim Az-Zarkaši ${ }^{31}$ definiše tefsir kao nauku pomoću koje se uči kako treba razumijevati Allahovu Knjigu, objavljenu Njegovom Vjerovjesniku Muhammedu, s.a.v.s., kako tumačiti značenja njenih riječi, kako izvoditi njene propise i crpiti mudre poruke, pomažući se pri tom znanjem iz opće jezikoslovne nauke, gramatike, sintakse, stilistike, osnova pravne nauke, različitih čitanja (kiraeta) Kur'ana, ne zanemarujući ni značaj pitanja povoda objave, pa ni derogirajućih i derogiranih ajeta. ${ }^{32}$

Evidentno je, dakle, da se u svim ovim definicijama ističe da su kiraeti (čitanja) Kur'ana časnog predmet interesovanja tefsirske nauke. Zbog toga klasična djela iz područja tefsira sadrže brojne tekstove u kojima se vidi kako su slavni komentatori Kur'ana tretirali kiraete u svojim tefsirima.

Al-Džassasovo tefsirsko djelo Ahkam al-Qur'an može poslužiti kao dobar primjer za analizu upotrebe kiraeta u tefsirskoj nauci. S

${ }^{29}$ Ovo je definicija koju je autor ovoga rada iznio u svome magistarskom radu na Odsjeku za tefsir i kur'anske nauke Univerziteta Al-Azhar u Kairu, u martu 1997. godine. Komisija za odbranu je prihvatila ovu definiciju bez ikakvih primjedbi, a teza je publikovana 1999. godine u izdanju kairske izdavačke kuće Dar an-nešr li aldžami'at. (Vidjeti: Safvet Halilović, At-Tafsir bi al-ma'thur - Ahamiyyatuhu wa dawabituhu, Dirasa tatbiqiyya fi sura an-Nisa', Kairo, 1420. H./1999., str. 20-21.

${ }^{30}$ Abu Hayyan al-Andalusi, Al-Bahr al-muhit, I, str. 13-14.

31 Muhammad ibn Behadur ibn 'Abdullah az-Zarkaši, poznat kao Badruddin azZarkaši (umro 794. H./1391.), istaknuti učenjak šafijskog mezheba. Slovi za jednog od najvećih poznavalaca usulske nauke. Rođen je i umro u Kairu. Autor je mnogih djela iz više naučnih oblasti od kojih su najpoznatija: Al-Burhan fi 'ulum al-Qur'an i Al-Bahr al-muhit - iz usulske znanosti. (Vidjeti: Ad-Durar al-kamina, III, str. 397; Al-A'lam, VI, str. 60.)

${ }^{32}$ Az-Zarkaši, Al-Burhan fi 'ulum al-Qur'an, I, str. 13. 
obzirom da je to djelo bilo tema naše doktorske disertacije na Azharovom odsjeku za tefsir i kur'anske nauke u Kairu, u nastavku ćemo donijeti više primjera iz njegovoga tefsira poznatog pod naslovom Ahkam al-Qur'an (Propisi Kur'ana). ${ }^{33}$

Prilikom pažljivog čitanja djela Ahkam al-Qur'an, odmah se primjećuje da njegov autor imam Abu-Bakr al-Razi al-Džassas posvećuje veliku pažnju prilikom tumačenja Kur'ana kiraetima Kur'ana. Moglo bi se reći da je neposredan razlog tome čvrsta povezanost kiraeta s komentarisanjem Kur'ana, naročito fikhskog komentarisanja kakvo je on praktikovao. Među učenjacima je bilo rašireno shvatanje da različiti kiraeti iznose različite propise. ${ }^{34} \mathrm{Na}$ drugoj strani, Al-Džassas je bio u prilici da tim umijećem veoma dobro ovlada dok je učio pred učiteljem Al-Farisijem, nekad učenikom istaknutog Ibn-Mudžahida, koji je sabrao kiraete sedmerice prvaka u djelu pod naslovom Kitab as-Sab'a fi al-qira'at. Al-Farisi je ovo djelo opširno komentirao obrativši posebnu pažnju obilježjima i usmjerenjima sedam kiraeta. Komentar je naslovio Al-Hudždža fi 'ilal al-qira'at as-sab'a. ${ }^{35}$

Al-Džassas je utvrdio da kiraete treba prihvatati putem slušanja i usmenog prenošenja, razumijevajući ih kao ono što je Vjerovjesnik, s.a.v.s., dostavio u sklopu Objave koju je primao. U tome je svojevrsno uputstvo onima koji su kasnije dolazili kako će preuzimati kiraete, jer kiraeti ne spadaju u područje u kojem presudno pomaže idžtihad. Dakako, idžtihad u području usmjeravanja kiraeta (tawdžih al-qira'at) i tumačenja njihovih obilježja je, bez dvojbe, opravdan i potreban, ali se mora imati na umu da je u osnovi kiraeta objavljeno znanje, a ne ljudski intelekt i promišljanje.

Česta pojava kod Al-Džassasa je to da on kiraet ne pripisuje autoritetima, već se zadovoljava samo time da kaže čita se - quri'a,

33 Disertacija je odbranjena u Kairu 2001. godine uz preporuku Komisije da se štampa zbog njenih naučnih vrijednosti. To je i učinjeno, iste godine, u izdanju kairske izdavačke kuće Dar as-salam. Disertaciju je kasnije na bosanski jezik preveo dr. Mehmed Kico i publikovana je 2004. godine u izdanju Fakulteta islamskih nauka i El-Kalema u Sarajevu. U ovom radu je korišten prijevod profesora Kice, uz izvjesna skraćivanja i dopune.

${ }^{34}$ Vidjeti: As-Suyuti, Al-Itqan fi 'ulum al-Qur'an, I, str. 141.

35 Vidjeti: Safvet Halilović, Abu Bakr ar-Razi al-Džassas wa manhadžuhu fi attafsir, Dar as-salam, Kairo, 2001., str. 102-104. 
nakon čega izlaže čitanje s karakterističnim obilježjima. Tako npr. u vezi s riječima Uzvišenoga: $i$ onome što je bilo objavljeno dvojici meleka, Harutu i Marutu, u Babilonu (Al-Baqara: 102) kaže: Čita se s fathom na lamu (al-malakayni) ili s kasrom ispod lama (al-malikayni). Ko pročita s fathom, datom riječju ima u vidu dva meleka, a ko pročita s kasrom, u vidu ima nešto drugo. ${ }^{36}$ Od Dahhaka se prenosi da su dvojica bila dva krupna čovjeka u Babilonu. Oba kiraeta su ispravna i međusobno se ne potiru, jer je moguće da je Allah u vrijeme dvaju vladara poslao dva meleka da ih svojom vještinom pobjede $u$ sihiru (vradžbini) i trikovima. Ako je dvojici meleka bilo zapovjeđeno da ljude upozore na opasnosti od sihira i njegove štetnosti, za jedno čitanje bismo mogli reći da glasi: I onome što je bilo objavljeno dvojici meleka koji su odista bili meleci i kojima je to objavljeno; a za drugo čitanje bi se moglo reći da glasi: I onome što je bilo objavljeno dvojici vladara iz reda ljudi, te da je dvojici vladara bilo zapovjeđeno da dostavljaju i poučavaju, onako kako je Uzvišeni Allah Svome Vjerovjesniku, s.a.v.s., uputio riječi: Mi tebi objavljujemo Knjigu kao objašnjenje za sve (An-Nahl: 89), a na drugome mjestu mu veli: Recite: Mi vjerujemo u Allaha $i$ u ono što se objavljuje nama (AlBaqara: 136), da bi činjenica objavljivanja jednom bila povezana $\mathrm{s}$ Poslanikom, s.a.v.s., a drugi put s onima kojima se objavljuje.

\footnotetext{
${ }^{36}$ Ibn-'Ašur u djelu At-Tahrir wa at-tanwir ističe: Prema'mutevatir kiraetu' čita se 'al-malakayn'i, a Ibn-'Abbas, Dahhak, Al-Hasan i Ibn-Abza su čitali, al-malikayni'. Dalje autor dodaje: I čitanje Ibn-'Abbasa i Al-Hasana (al-malikayni) ima ispravno značenje. Ono znači da su u Babilonu vladala dva vladara koji su poznavali sihir (magiju, vradžbinu). Čak $i$ ako se čita s fathom (al-malakayni), moglo bi se tumačiti metaforom, da se radilo o dvojici dobrih ljudi koji su vladali Babilonom a poznavali su sihir, bili pronikli u tajne vradžbine koje su sihirbazi donosili u Babilon, ili su joj uspostavili temelje u formi s kojom nije imala primjese nevjerovanja, u koju su ljudi kasnije unijeli krivovjerstvo i nevjerovanje. Neki kažu da su to bila dva meleka koje je Allah poslao u ljudskom liku da ljude poučavaju sihiru, kako bi otkrili tajne onih koji se njime bave. Sihirbazi (ar. as-sahara) su za sebe tvrdili da su bogovi ili vjerovjesnici, a narod im se potčinjavao. Zbog toga je Allah htio pokazati da sihirbazi lažu kad tvrde da su vjerovjesnici. Zbog toga je poslao dva meleka. Time se poručuje da je poučavanje sihira u vrijeme Haruta i Maruta bilo praktikovano radi prevladavanja iskušenja na koja Allah stavlja Svoje robove tako što pokornoga to nije privlačilo, a nepokoran je, pak, tome težio čineći tako grijeh. Neki, dalje, kažu da je Allah, dž. š. Talutov narod na sličan način stavio na iskušenje rijekom... (Vidjeti: Ibn-'Ašur, At-Tahrir wa at-tanwir, I. str. 639-641.)
} 
Posebno treba naglasiti mogućnost da se radi o vladarima kojima je bilo zapovjeđeno da poučavaju sve ostale, jer je običan svijet slijedio vladare. Sasvim primjereno je da definiranje sihira i dokazivanje njegove štetnosti ljudima, kao sljedbenicima, uvjerljivo mogu iznijeti vladari. S takvim smislom je Allah rekao Musau i Harunu: Idite faraonu, on se, doista, osilio. Blagim mu riječima govorite, ne bi li razmislio ili se pobojao. (Ta-Ha: 43-44) Premda su njih dvojica bili poslanici faraonovim podanicima kao i samom faraonu, njemu se posebno upućuje poruka, jer je to trebao biti najdjelotvorniji put pozivanja $u$ islam, pozivom upućenim najprije vladaru, a tek potom njegovim podanicima. Tako je Poslanik, s.a.v.s., pisao (perzijskom) Kisri i (bizantijskom) caru. Poziv je uputio njima lično, a ne njihovim podanicima, premda je on poslanik cijelom svijetu. Ovo s razlogom koji smo naprijed opisali, zato što se podanici okupljaju oko svoga vladara." ${ }^{37}$

Drugi primjer Al-Džassasovog razmatranja kiraeta $\mathrm{u}$ tefsiru ogleda se u komentiranju riječi Uzvišenog Allaha: I neka vas mržnja koju prema nekim ljudima nosite, zato što su vam spriječili pristup Časnom hramu, nikako ne navede da ih napadnete (Al-Ma'ida: 2), kad kaže: 'Riječi Uzvišenoga: mržnja prema ljudima (šana'an qawm) čitaju se $\mathrm{s}$ fathom ili sukunom na nunu. ${ }^{38}$ Ko pročita $\mathrm{s}$ fathom na nunu, oblikuje to kao infinitiv (masdar) glagola šana'a yašna'u (šana'anun), a šana'anun je mržnja, slično omrazi (bugd)', kao da je rečeno: 'I neka vas omraza prema nekim ljudima ne spriječi.' Isto se prenosi od Ibn'Abbasa i Qatade, a kod njih to znači neprijateljstvo. Ko pročita sa sukunom na nunu, oblikuje značenje mrzitelj druge zajednice. U tom slučaju, poruka znači da Allah ovim ajetom zabranjuje da za račun nasilja pogaze pravdu zbog toga što su krivovjernici prekoračili granicu zabranivši muslimanima ulazak u krug Časnoga hrama. ${ }^{39}$

Evidentno je da Al-Džassas ponekad, dok govori o obilježjima nekog kiraeta, citira stavove nekog autoriteta navodeći predaje koje sežu do autoriteta, na osnovu vlastitog predajnog lanca, ali bez toga da

\footnotetext{
${ }^{37}$ Ahkam al-Qur'an, I, str. 67-68.

${ }^{38}$ Ibn-Kathir, Abu-'Amr i Hamza al-Kisa'i su čitali s fathom na nunu, a Ibn-'Amir sa sukunom. U vezi s Asimovim i Nafi'ovim čitanjem predaje se razlikuju tako, što se negdje ističe da su čitali s fathom, a negdje da su čitali sa sukunom. (Vidjeti: IbnMudžahid, Kitab as-Sab'a fi al-qira'at, str. 242.)

${ }^{39}$ Ahkam al-Qur'an, II, str. 381.
} 
spomene kako je dotični autoritet čitao taj tekst. Takvim primjerom se doima ono što je kazao u komentaru riječi Uzvišenog Allaha: ako jedna od njih dvije zaboravi, neka je druga podsjeti (Al-Baqara: 282), uz koje, na osnovu svoga predajnog lanca izlaže čitanje Ibn- 'Amira, ističući: Čita se 'tudhakkira', sa těśdidom, a čita se $i$ 'tudhkira', tj. oduzimanjem vokala. ${ }^{40}$ Neki kažu da oba čitanja oblikuju isto značenje, kao kad se kaže dhakartuhu ili dhakkartuhu (spomenuo sam ga). Ovako se prenosi od Ar-Rabi’a ibn Anasa, As-Suddija i AlDahhaka. 'Abd al-Baqi ibn Qani' nam je kazivao: Kazao nam je Abu'Ubayd Mu'ammil as-Sirafi rekavši: Kazao nam je Abu-Ya la al-Basri rekavši: Kazao nam je Al-Asma'i, koji prenosi od Abu-'Amra da je rekao: Ko pročita 'fa tudhkira', bez vokala, želi reći da svjedočenje njih dvije ima snagu svjedočenja jednoga muškarca, a ko pročita 'fa tudhakkira', sa tešdidom, želi izraziti podsjećanje. Ovako se prenosi od Sufyana ibn 'Uyayne.

Abu-Bakr (Al-Džassas) kaže: Ako su ova oba značenja moguća, svako od dva 'čitanja' treba saobraziti s onim drugim i primijeniti na njega i novo značenje. Tako bi riječi iz Allahovoga, dž. š., govora 'fa tudhkira', bez vokala, obrazovale značenje svjedočenja dviju žena sa snagom svjedočenja jednog muškarca, a 'fa tudhakkira', sa tešdidom, značilo bi podsjećanje u slučaju zaborava. Korištenje svakog od dva značenja u kombinaciji s drugim podesnije je nego da se ono svodi samo na jedno. ${ }^{41}$

\section{Razgranavanje značenja putem razgranavanja kiraeta}

Iz prethodnoga Al-Džassasovog izlaganja može se sagledati kako on smatra da je saobražavanje različitih kiraeta zahtjevima poruke i praktične primjene, koliko god je to moguće, uputnije od svođenja na značenje samo jednoga kiraeta, jer $\mathrm{u}$ tome postoji mogućnost razgranavanja značenja. Takav postupak možemo vidjeti i na brojnim drugim mjestima u njegovom tefsiru kao npr. u komentaru riječi Allaha Uzvišenoga: $i$ neka ne bude oštećen ni pisar ni svjedok (Al-Baqara: 282), kad kaže: Al-Hasan i Qatada su čitali 'wa la

\footnotetext{
${ }^{40}$ Čitanje s oduzetim vokalom Ibn-Mudžahid pripisuje Abu-'Amiru i Ibn-Kathiru, a s tešdidom preostaloj peterici od sedam autoriteta. (Vidjeti: Ibn-Mudžahid, o. c. str. 193.)

${ }^{41}$ Ahkam al-Qur'an, I, str. 621.
} 
yudarri', s kasrom na rau, dok su Abdullah ibn Mas `ud i Mudžahid čitali 'wa la yudarra', s fathom na rau. Jednim 'čitanjem' se potražiocu zabranjuje da nanesu štetu pisaru i svjedoku, a drugim čitanjem se pisaru i svjedoku zabranjuje da naštete potražiocu. Oba 'čitanja' su ispravna i praktikuju se. Potražiocu je zabranjeno da našteti pisaru $i$ svjedoku, tako što će ih zaokupiti nečim na osnovu čega ih može navesti da se bilježi $i$ svjedoči njemu u korist, a istovremeno se $i$ pisaru i svjedoku zabranjuje da potražiocu nanesu štetu, tako što će pisar bilježiti kako nije bilo, a svjedok svjedočiti drugačije nego što je vidio. Šteta koju svjedok može pričiniti jeste $i$ odustajanje od svjedočenja, a svjedočenje je nepotpuno ako nema dva svjedoka. Njima je stroga dužnost da svjedočenje ispune, a neispunjenje svjedočenja suzdržavanjem jeste nanošenje štete potražiocu. Pisar je dužan to bilježiti ako ne nađu nekog drugog. ${ }^{42}$

Iste je naravi i ono što obuhvata Al-Džassasov komentar riječi Uzvišenoga Allaha: O vjernici, jedni drugima na nedozvoljen način imanja ne prisvajajte, ali dozvoljeno vam je trgovanje uz obostrani pristanak (An-Nisa': 29), gdje kaže: U Allahovim riječima: ali dozvoljeno vam je trgovanje uz obostrani pristanak, riječ 'trgovina' se čita u akuzativu (tidžaratan) ili u nominativu (tidžaratun). Onaj ko čita u akuzativu želi naglasiti izuzimanje trgovine uz obostrani pristanak po tome što trgovina proizlazi iz obostrane volje i po tome se izuzima iz zabrane prisvajanja imetka, premda se prisvajanje imetka može ostvarivati i preko neke vrste trgovine kao i mimo trgovine. Ovdje se trgovina iz zabrane o prisvajanju izuzima po tome što nije bespravno prisvajanje imovine. Onaj, pak, ko čita u nominativu želi reći samo da to bude 'trgovina', slično distihu pjesnika:

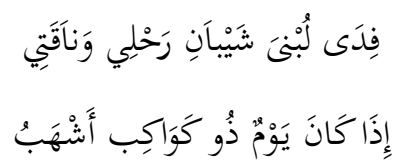

Dok me kamila nosi vjetru niz struju,

Posmatram zvijezde kroz pješčanu oluju;

Što će reći da se zvijezde vide $i$ usred oluje. Tako se može raspoznati $i$ sve ono što se ne bi smjelo prisvajati. Iz toga ništa ne

42 o. c., str. 633 . 
može biti izuzeto. Tu apsolutno nema izuzetka, osim kad se radi o trgovini uz obostrani pristanak, koja je, nesumnjivo, dozvoljena. ${ }^{43}$

\section{Saobražavanje kiraeta}

Nije teško primijetiti ni to da Al-Džassas ponekad na različita čitanja datoga kur'anskoga izraza primjenjuje samo jedan oslonac. Drugim riječima, svodi im značenje na ono što oblikuje značenje jednoga čitanja, radi toga što on jedno od čitanja smatra jasnim; a jasno kod Al-Džassasa je ono što može imati samo jedan smisao; dok druga čitanja smatra manje jasnim, odnosno višesmislenim. U takvim situacijama Al-Džassas smatra, kako je svođenje na ono što nalaže smisao čitanja $\mathrm{s}$ jasnim značenjem i saobražavanje manje jasnoga $\mathrm{s}$ jasnim, bolje od naslanjanja svakog čitanja na ono što oblikuje njegovo značenje. Ovakav njegov postupak možemo ilustrirati na sljedeća dva primjera.

Prvi primjer se ogleda u onome što je Al-Džassas rekao prilikom komentara riječi Allaha Uzvišenoga: i ne prilazite im dok se ne očiste. A kada se očiste, onda im prilazite onako kako je Allah naredio (Al-Baqara: 222), gdje kaže: Riječi Uzvišenoga: 'Dok se ne očiste', ako se pročitaju bez vokala (na tau), znači' čišćenje' u smislu prestanka krvi, a ne 'kupanje', budući da sve i da se okupaju ako još krvare, žene nisu čiste. Zato Allahove riječi: 'Dok se ne očiste' podrazumijevaju samo jedan smisao, a to je prestanak krvi koja teče tokom mjesečnice. Ako se ista riječ pročita sa tešdidom, ona može pretpostavljati dva smisla, 'prestanak krvi' i 'kupanje', kako smo već naprijed spomenuli. U tom slučaju je 'čitanje' bez vokala 'jasno', a sa tešdidom 'manje' jasno 'čitanje'.

Dalje, prosudbu o manje jasnom. treba saobraziti sa jasnim $i$ tada se od smislova dvaju 'ćitanja' dobiva jedan, po kojem će biti jasno da stupanje u spolni odnos sa ženama postaje dozvoljeno $s$ prestankom krvi koja je tekla za vrijeme mjesečnice. Što se tiče riječi Uzvišenoga: 'A kada se očiste', podrazumijevaju upravo ono što podrazumijeva 'ćitanje' sa tešdidom: 'Dok se ne očiste i ne okupaju', sa dva obuhvaćena značenja, a nakon toga, u kontekstu s preostalim riječima: 'I ne prilazite im dok se ne očiste', a zatim: 'A kada se

${ }^{43}$ o. c., II, str. 220. 
okupaju, onda im prilazite onako kako je Allah naredio', poruka postaje precizna i jasna, kao kad se kaže: 'Ne daj mu to prije nego uđe u kuću, a kad uđe, podaj mu.' Data riječ u kontekstu jasno nudi prosudbu o cilju, premda se razlikuje od prosudbe o onome što joj je prethodilo. Pošto je moguće oslonac tražiti na način koji smo spomenuli, dužnost nam je da cilj saobrazimo sa pravim smislom. Prema tome, ono što nalaže vidljivo značenje ovog ajeta, jeste dopuštanje snošaja sa ženama nakon što prestane krv koja je tekla tokom mjesečnice. ${ }^{44}$

Drugi primjer ogleda se u onom što je Al-Džassas rekao u vezi s riječima Uzvišenoga Allaha: Allah vas neće kazniti ako se zakunete nenamjerno, ali će vas kazniti ako se zakunete namjerno (Al-Ma'ida: 89), gdje kaže: U govoru Uzvišenoga: 'Ako se zakunete namjerno', jedna riječ se čita na tri načina. Neki čitaju 'aqqadtum' - sa tešdidom; drugi 'aqadtum' - bez tešdida; a neki 'aaqadtum' - sa dugim vokalom na 'aynu. ${ }^{45}$ Riječ Uzvišenoga aqqadtum, prema mišljenju Abu alHasana (Al-Karkija), sa tešdidom, podrazumijeva samo govorni čin, a $\mathrm{u}$ varijanti aqadtum, bez tešdida, podrazumijeva spremnost srca (qalb), a to je namjera i odluka na govorni čin kao i čin zakletve riječima. Ako jedno od dva čitanja podrazumijeva govorni čin $\mathrm{i}$ spremnost srca, drugo može podrazumijevati samo čin zakletve riječima. Dalje, ono što podrazumijeva dva značenja, treba saobraziti onome što podrazumijeva samo jedno. Tad će smisao i jednoga $\mathrm{i}$ drugoga čitanja biti čin zakletve riječima. Obaveznost iskupa zbog zakletve tada će biti ograničena na ovaj primjer zaklinjanja, a to je zaklinjanje na nešto što traje, koje se ne odnosi na zaklinjanje prošlosti, jer to nije čvrsto zaklinjanje već kazivanje o prošlosti, a kazivanje o prošlosti nije zakletva govorom, svejedno da li je on istinit ili lažan.

Ako bi neko rekao: Ukoliko se data riječ Uzvišenoga pročita 'aqadtum', bez tešdida, može imati dva značenja: uvjerenost srca i čin izgovaranja zakletve; pa zašto joj niste dali oba značenja jer se

\footnotetext{
${ }^{44}$ Ibid., I, str. 423.

${ }^{45}$ Ibn-Kathir, Nafi', Abu-'Amr, 'Asim, prema Hafsovom kazivanju, čitaju 'aqqadtum, sa tešdidom. Hamza al-Kisa'i i 'Asim, prema kazivanju Abu-Bakra, čitaju 'aqadtum, bez tešdida; dok Ibn-'Amir čita 'aaqadtum, s dugim vokalom na 'aynu. (Više o tome vidjeti: Ibn-Mudžahid, o. c., str. 247.)
} 
međusobno ne potiru!? Slično i varijanta 'aqqadtum', sa tešdidom, podrazumijeva čin zakletve ne potirući mogućnost korištenja riječi sa značenjem odluke na zakletvu, što može važiti kao opća pojava u vezi sa zakletvom. Mi na takva razmišljanja odgovaramo: Kad bismo se složili s tobom u vezi mogućnosti koju spominješ, ne bi bila dozvoljena njena upotreba $u$ onom što navodiš, a $i$ konsenzus učenjaka ne dozvoljava da se tako protumači, jer nije sporno da se obaveznost iskupa ne veže za namjeru zakletve, već za formulaciju u zakletvi čija je posljedica obaveznost iskupa. To opovrgava tumačenje onoga ko tumačenje riječi zasniva na spremnosti srca kad se radi o propisu o otkupu, čime se istodobno potvrđuje da se s oba 'čitanja' zajedno, kad je u pitanju obaveznost iskupa, misli na zakletvu koja se odnosi na budućnost. $^{46}$

\section{Utvrđivanje tawatura u kiraetima}

Islamski učenjaci su prilikom definiranja Kur'ana časnog govorili o njemu kao o nadnaravnome Allahovom govoru, objavljenom Muhammedu, s.a.v.s., čijim učenjem se vrši poseban ibadet, koji je zabilježen u mushafima, prenesen putem apsolutno pouzdanih (mutawatir) predajnih lanaca. U predmetnim se definicijama ističe kako je Kur'an ono što se prenosi 'mutawatir' predajom. Otuda i stav Ibn al-Džazarija, iznesen u djelu Mundžid almuqri'in, da bi uvjet pouzdanosti predajnog lanca (sihha al-isnad), na kojem se insistira prilikom postavljanja uvjeta prihvatljivih 'čitanja', trebalo zamijeniti uvjetom velikoga broja pouzdanih ljudi u predajnom lancu (tawatur al-isnad), jer da bi se nešto smatralo Kur'anom mora biti preneseno upravo takvom vrstom predaje (mutawatir). ${ }^{47}$

Ako obratimo pažnju na način kojim se Al-Džassas u tefsiru odnosio prema kiraetima (čitanjima), vidjet ćemo da je veoma pažljivo provjeravao njihovu autentičnost i način prenošenja, jer nisu svi kiraeti preneseni putem mutevatir predaje. Shodno tome, svi ne mogu biti izraz Kur'ana kojim se može vršiti bogoslužje (ibadet), odnosno izraz koji se može učiti u namazu. Tako Al-Džassas uz riječi Uzvišenoga: I pomajke vaše koje su vas dojile i sestre vaše po mlijeku

\footnotetext{
${ }^{46}$ Ahkam al-Qur'an, II, str. 569.

${ }^{47}$ Abu al-Qasim an-Nuwayri, Muqaddima li šarh Tayba an-Našr fi qira'at al-'ašr, str. 73-78; : Subhi as-Salih, op. cit. str. 255-256; 'Abd al-Fattah al-Qadi, o. c., str. 9.
} 
(An-Nisa': 23), razmatra pitanje žena zabranjenih $\mathrm{s}$ razlogom kratkotrajnog dojenja (qalil ar-rada), u vezi $\mathrm{s}$ kojim navodi razmimoilaženja prethodnika. Prilikom razmatranja ovoga pitanja navodi argumente onih koji smatraju da zabrane nema bez pet navrata dojenja. To je stav šafi ijskog mezheba utemeljen na predaji od Aiše, r.a., koja kaže: Po onome što je objavljeno u Kur'anu, radilo se o deset neupitnih dojenja, što je derogirano s pet neupitnih dojenja. Allahov Poslanik, s.a.v.s., je umro, a propis je ostao utemeljen na onome kako se čitalo iz Kur'ana. ${ }^{48}$ Al-Džassas na to iznosi svoj komentar:

Što se tiče Aišinoga kazivanja, ono se ne može prihvatiti kao ispravno u ovakvoj formi zato što ona veli da je 'po onom što je objavljeno u Kur'anu bilo deset, pa je to derogirano s pet dojenja, te da je Allahov Poslanik, s.a.v.s., umro, a to se $i$ dalje na isti način čitalo'. Međutim, općepoznato je da niko nakon Poslanikove, s.a.v.s., smrti nije mogao derogirati ništa iz Kur'ana. Da je kazivanje utemeljeno, bilo bi potvrđeno postojanjem odgovarajućeg kiraeta (čitanja). Međutim, ako takav kiraet ne postoji, a budući da nije moguće derogiranje nakon smrti Vjerovjesnika, s.a.v.s., kazivanje nije lišeno jednoga od dva smisla: ili da je kazivanje podmetnuto i kao takvo nije obavezujuće, ili je ono doista postojalo pa je za života Allahovog Poslanika, s.a.v.s., derogirano. U svakome slučaju, postupati po onome što je derogirano nije dozvoljeno. Moguće je i da je to bio propis vezan za dojenje odrasle osobe (rada' al-kabir) o kojem je Aiša, jedina iz reda Vjerovjesnikovih, s.a.v.s., supruga, govorila u vezi sa zabranom žena uslijed takvog dojenja. Mi smo, kao i Šafija, utvrdili da je pitanje dojenja odrasle osobe derogirano. Tako je postao nevažeći propis o određivanju deset dojenja koji se spominju u Aišinom kazivanju. Neovisno od toga, taman kad bi ovo kazivanje bilo lišeno protivrječnosti i nagađanja koja smo spomenuli, ne bi bilo moguće suprotstaviti se njime jasnom značenju Kur'ana budući da je to kazivanje pojedinaca. U ono što potvrđuje naš stav o neodrživosti navedenog propisa spada $i$ to što dojenje nalaže trajnu zabranu, slično spolnom odnosu u vezi s kojim se zabranjuje majka i kćerka, kao i činu kojim se nalaže zabrana žena s kojima su se oženili očevi ili sinovi. Budući da u svemu tome malobrojnost ima tretman isti kao $i$

${ }^{48}$ Vidjeti: Ahkam al-Qur'an, II, str. 159. 
mnogobrojnost, tako i kratkotrajno dojenje mora rezultirati zabranom sklapanja braka zbog srodstva po mlijeku.

Drugi primjer govori o Al-Džassasovoj živoj zainteresovanosti da utvrđuje tawatur u kiraetima, a to je njegov komentar na riječi Uzvišenog Allaha: A ženama vašim s kojima ste imali bračne odnose podajte vjenčane darove njihove kao što je propisano (An-Nisa': 24), u vezi s kojim, navodeći kiraet Ubayya ibn Ka'ba, veli: Prenosi se da u čitanju Ubayya ibn Ka'ba stoji: 'A ženama vašim s kojima ste imali bračne odnose, do roka određenog, podajte vjenčane darove njihove', što je kasnije, nakon što je pitanje prodiskutovao s nekima koji su u ovom ajetu našli argumente o legalnosti privremenog braka (nikah almut'a), drugačije komentarisao: 'Što se tiče argumenata onih koji žele dokazati da se riječima Uzvišenoga: 'A ženama vašim s kojima ste imali bračne odnose podajte vjenčane darove njihove kao što je propisano', podrazumijeva ono što je čitao Ubayy ibn Ka'b 'do određenog roka', to je nešto što ne može naći primjenu u 'čitanju' nijednoga muslimana. Dakle, rok se ne potvrđuje Kur'anom. Kad bi to bilo $i$ spomenuto, opet ne bi ukazivalo na legalnost privremenog braka, jer je moguće da rok bude povezan s vjenčanim darom, u kojem slučaju bi precizni propis glasio: 'I vjenčane darove koje ste im $s$ određenim rokom obećali dati, podajte im ih sistekom roka. ${ }^{49}$

\section{Drugačiji propis uz drugačiji kiraet}

Naprijed se, u uvodnim napomenama, moglo vidjeti da je obraćanje pomne pažnje kiraetima i njihovom diferenciranju veoma važno u području komentiranja Kur'ana, posebno u onome što se tiče fikha i propisa. Zbog toga učenjaci ističu kako drugačije čitanje (kiraet) za sobom povlači drugačiji propis (ikhtilaf al-qira'at yuzhir ikhtilaf al-ahkam). ${ }^{50}$ To se jasno vidi u Al-Džassasovom tefsiru, u šta se čitalac može uvjeriti na brojnim mjestima,od kojih navodima dva.

Prvo mjesto: Tiče se komentara riječi Uzvišenoga Allaha: $A$ kada one kao udate počine blud, neka se kazne polovicom kazne propisane za slobodne žene (An-Nisa': 25), u sklopu kojega kaže: Čita

\footnotetext{
${ }^{49}$ o. c., II, str. 185-186.

${ }^{50}$ Vidjeti: As-Suyuti, Al-Itqan fi 'ulum al-Qur'an, I, str. 141.
} 
se 'fa idha ahsanna', s 'fathom' na 'alifu',51 i 'uhsinna', s 'dammom' na 'alifu'. Prema Ibn- 'Abbasu, Sa'idu ibn Džubayru, Mudžahidu i Qatadi 'uhsinna', s 'dammom', znači 'yatazawwadžna' (udale se), a prema 'Umaru, Ibn-Mas'udu, Ǎs-Ša'biju i Ibrahimu an-Nakha'iju 'ahsanna', s 'fathom', znači 'aslamna' (prihvatile islam). Hasan al-Basri je rekao: 'Zaštićenom je čini muž, a zaštićenom je čini i islam.'

Prethodnici su se razmimoilazili oko mjere namijenjene robinji. Tumače riječi Uzvišenoga: 'Fa idha uhsinna', neki su u njihov smisao uključivali $i$ udaju. U vezi s robinjom, tvrdili su da nije potrebna nikakva mjera ako je prihvatila islam, makar $i$ ne bila udana. To je naučavanje Ibn- 'Abbasa i onih koji ga slijede. Onaj ko to čita: 'Fa idha ahsanna' (ako su zaštićene), tako što su prihvatile islam, a nakon toga počinile blud, propisuje im se mjera, makar i ne bile udane. To je stav Ibn-Mas'uda $i$ onih koji njega slijede. Neki, pak, kažu: 'Tumačenje zasnovano na prihvatanju islama je malo vjerovatno, jer je vjerovanje već ranije naglašavano riječima Uzvišenoga: 'robinje vaše, vjernice (An-Nisa': 25)', a daleko je da se kaže: 'Robinje vaše, vjernice, ako vjeruju.' Nije to baš tako kako se misli, jer riječi Uzvišenoga: 'robinje vaše, vjernice', odnose se na bračne odnose, pogotovo zato što je već naprijed spomenut jedan drugi propis kao mjera. Međutim, moguće bi bilo da je naprijed spomenut islam. Formulacija bi tada glasila: 'Ako kao muslimanke počine blud', što niko ne bi odbio kao nemoguće premda je to neprihvatljivo prema viđenju 'Umara, Ibn-Mas'uda i njihovih istomišljenika, čiji smo stav navodili. Nema zapreke da se ovdje misli na oba aspekta - islam $i$ brak, zajedno, da se zajedno podrazumijevaju, da prethodnici na njima jednako zasnivaju tumačenje ovoga ajeta.

Drugo mjesto: Tu se donosi ono što je Al-Džassas rekao tumačeći riječi Uzvišenoga: A dio glava svojih potarite $i$ noge svoje do iza članaka (Al-Ma'ida: 6), gdje kaže: Ibn-'Abbas, Al-Hasan, 'Ikrima, Hamza i Ibn-Kathir čitaju 'wa ardžulikum', s 'kasrom', da bi to tumačili 'potiranjem nogu'. 'Ali, 'Abdullah ibn Mas'ud, Ibn-'Abbas,

\footnotetext{
${ }^{51} \mathrm{~S}$ fathom, tj. fa idha ahsanna, prema predaji Al-Mufaddala i Abu-Bakra, čitali su Al-Kisai, Hamza i 'Asim, dok su s dammom, tj. fa idha uhsinna, prema Hafsovoj predaji, čitali su Ibn-Kathir, Nafi', Abu-'Amr, Ibn-'Amir i 'Asim. (Vidjeti: IbnMudžahid, op. cit. str. 231.)

${ }^{52}$ Ahkam al-Qur'an, II, str. 211-212.
} 
prema predaji od Ibrahima, Ad-Dahhaka, Nafi'a, Ibn-'Amira, AlKisaija, Hafsa, preuzetoj od 'Asima, čitali su 'wa ardžulakum', s 'fathom', tumačeći da je dužnost prati noge. ${ }^{53} \mathrm{Od}$ Al-Hasana al-Basrija je sačuvan stav da potiranjem treba obuhvatiti cijelu nogu, ali se ne sjećamo više nikoga od prethodnika ko je dozvolio potiranje noge, bilo cijele ili njenoga jednog dijela. Neki kažu: Kad se radi o potiranju, ono je nesumnjivo djelomično, ali među znamenitim fakihima nema razmimoilaženja o tome da se ovdje misli na 'pranje.'

Na oba ova čitanja objavljen je Kur'an, a ummet ih je preuzeo slušajući ih od Allahovoga Poslanika, s.a.v.s. Jezikoslovci se ne razilaze oko toga da se u oba čitanja (kiraeta) podrazumijeva potiranje ako se u iskazu stopala dovode u vezu s glavom, kao i da se podrazumijeva pranje ako se stopala dovedu u vezu s ostalim dijelovima tijela. Radi toga što se Allahovim riječima 'wa ardžulakum', u akuzativu, moglo ciljati na sljedeći smisao: 'Operite svoja stopala'. Međutim, moguće je i da su se stopala željela pridružiti glavi, te da se time mislilo na potiranje premda je u akuzativu, stoga što je pridodano po smislu a ne po izgovoru, budući da je i ono što se potire objekat glagolske radnje, slično onome kako stoji u poruci pjesnika:

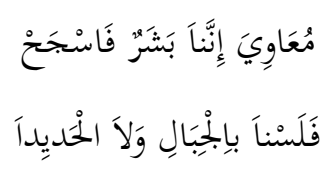

Muavija, mi smo ljudi, malo stege skini,

Nismo mi gvožđe ni kamenje u planini.

"Gvožđe" u akuzativu je ovdje po smislu povezano s planinama. Čitanje u genitivu podrazumijeva pridruživanje stopala glavi i time se misli na potiranje, ali se može pretpostaviti i pridruživanje onome što treba prati. U genitivu će tada biti samo zbog slijeda u iskazu, kao u riječima Uzvišenoga: 'Služit će ih vječno mladi mladići' (Al-Waqi'a: 17), iza kojih ubrzo dolaze riječi: 'U njima će biti $i$ hurije očiju krupnih' (Al-Waqi'a: 22), koje hurije dovode u vezu s mladićima tako što će i one služiti, a neće biti služene.

${ }^{53}$ Vidjeti: Ibn-Mudžahid, o. c., str. 242-243. 
Na osnovu ovoga što smo iznijeli, potvrđuje se pretpostavka da se sa svakim od dva 'čitanja' želi i potiranje i pranje.

Prema onome što smo opisali, potvrdilo se da oba 'čitanja' podrazumijevaju i potiranje i pranje. U tom slučaju, iskaz nije lišen jednoga od tri značenja: da se željelo reći oboje zajedno, da se u skladu s tim i potare $i$ opere, čime bi dvoje bilo kombinirano; da se radi o mogućnosti da onaj ko se abdesti po želji, bira jedno od dvoje, te da šta god izabere bude prihvatljivo; ili da se iskazom mislilo na samo jedno od dvoga, ali striktno, a ne da se proizvoljno bira. Međutim, nije ispravno reći da se ovim mislilo istovremeno $i$ na potiranje i na pranje, jer su svi učenjaci saglasni da onaj ko uzima abdest ne treba obje radnje činiti. Također, nije moguće da se uz jedno dopušta izbor po želji, jer se u ajetu nigdje ne spominje mogućnost izbora. Kad bi bilo moguće ustanoviti mogućnost izbora bez uporišta u riječi 'izbor' u ajetu, bilo bi moguće $i$ ustanovljenje spajanja bez uporišta u riječi 'spajanje'. Sudeći po svemu što smo opisali, izbor je neutemeljen.

Ako se eliminira izbor i spajanje dvoga, ne ostaje ništa nego da se misli na jedno bez mogućnosti izbora, što nameće potrebu da se iznađe dokaz na što se tačno misli. Dokaz je to što je pranje, a ne potiranje, nešto sa čim su svi suglasni, po tome što se, ukoliko se opere, ispuni dužnost $i$ obavi željeno. Tako izvršilac neće biti ukoren zbog ostavljanja potiranja, čime se potvrđuje da se mislilo na pranje. Osim toga, ako se stane na stanovištu koje smo iznijeli, da riječ podrazumijeva svako od dva značenja, uz suglasnost svih da se cilja na jedno od njih, ono što je sumarno kao dokaz postaje nedovoljno. Međutim, zato za svaki dokaz koji stiže od Poslanika, s.a.v.s., postupkom ili riječju, znamo da je ono na što Uzvišeni Allah upućuje. Od Poslanika, s.a.v.s., je i riječju i djelom stigao dokaz da je to pranje u abdestu. Učenjaci su u tome suglasni. Kada Poslanikov, s.a.v.s., postupak dođe kao pojašnjenje sumarnog iskaza (warad mawrid albayan), u tom je slučaju njegov postupak za vjernike obavezujući ('ala al-wudžub). Time se potvrđuje da je Uzvišeni Allah upravo to želio ovim ajetom. ${ }^{54}$

${ }^{54}$ Ahkam al-Qur'an, II, str. 433-434. 
Nakon toga, Al-Džassas je naveo detaljne argumente zasnovane na predaji od Poslanika, s.a.v.s., u kojima se jasno ističe da je obaveza prati noge prilikom uzimanja abdesta. ${ }^{55}$

\section{Zaključak}

Kiraeti imaju izuzetno važno mjesto u tefsirskoj nauci. U ovome su radu izneseni primjeri koji jasno pokazuju da različito izgovaranje određenih kur'anskih riječi kao posljedicu može imati i različit propis, odnosno značenje kur'anskog teksta.

S obzirom da je tevatur (brojnost prenosilaca određenog čitanja - kiraeta) glavni uvjet za prihvatanje nekog kiraeta, komentatori Kur'ana posvećivali su u svojim tefsirima veliku pažnju utvrđivanju tevatura $u$ kiraetima, ali istovremeno nije zanemarena ni druga dimenzija u ovoj značajnoj oblasti - a to je pravilno usmjeravanje svakog validnog kiraeta i detaljno objašnjenje značenja koje on u sebi sadrži.

Mogućnost izgovaranja pojedinih riječi Kur'ana na više načina govori, zapravo, o veličini i univerzalnosti kur'anskoga teksta. Kur'an je Božiji govor, njegova značenja su neiscrpna i ne mogu biti svedena na neku, vremenom ograničenu dimenziju ljudskog shvatanja.

\section{Literatura:}

1. Abu-Hayyan al-Andalusi, Al-Bahr al-muhit, Matba'a as-Sa'ada, Kairo, 1382. H./1967.

2. Ad-Dani Abu 'Amr, At-Taysir fi al-qira'at as-sab'a, priredio i objavio Pretzel, 1930.

3. Al-Bukhari Abu-'Abdullah Muhammad ibn Isma'il, As-Sahih, izdanje AlMadžlis al-a'la li aš-šu'un al-islamiyya, Kairo, bez godine izdanja.

4. Al-Farisi Abu 'Ali, Al-Hudždža li al-qurra' as-sab'a, Dar al-Ma'mun li al-turath, Damask, 1404. H./1983.

5. Al-Khatib al-Bagdadi, Tarikh Bagdad, Al-Maktaba as-salafiyya, Medina, Saudijska Arabija, bez godine izdanja.

55 o. c., II, str. 434-435. 
6. Al-Qadi 'Abd al-Fattah, Al-Budur az-zahira fi al-qira'at al-'ašr al-mutawatira min tariqay Ǎs-Šatibiyya wa Ad-Durra, Dar al-kitab al-'arabi, Bejrut, 1401. H./1981.

7. Al-Qadi 'Abd al-Fattah, Al-Qira'at aš-šadhdha wa tawdžihuha min luga al-'Arab (štampano kao dodatak djelu Al-Budur al-zahira fi al-qira'at al-'ašr almutawatira min tariqay Ǎs-Šatibiyya wa Ad-Durra), Dar al-kitab al-'arabi, Bejrut, 1401. H./1981.

8. Al-Qaradawi Yusuf, Kayf nata'amal ma'a al-Qur'an al-'azim, Dar aš-šuruq, Kairo, 1419. H./1999.

9. Al-Qaradawi Yusuf, Al-Mardži'iyya al-ulya fi al-islam li al-Qur'an wa as-sunna, Maktaba Wahba, Kairo, bez godine izdanja.

10. Al-Qasabi Mahmud Zalat, Al-Qurtubi wa manhadžuhu fi at-tafsir, Dar al-qalam, Kuvajt, 1401.H./1981.

11. Al-Qurtubi Abu-'Abdullah, Tafsir al-Qurtubi (poznato i kao: Al-Džami' li ahkam al-Qur'an), Dar aš-ša'b, Kairo, 1372. H./1952.

12. Al-Wahidi 'Ali ibn Ahmad ibn Muhammad: Asbab an-nuzul (štampano na marginama djela An-Nasikh wa al-mansukh, autor Abu al-Qasim Hibatullah), Kairo, 1351. H./1932.

13. Ar-Razi Fakhr ad-Din, At-Tafsir al-kabir (poznat i kao: Mafatih al-gayb), Dar alihya' li al-turath al-'arabi, drugo izdanje, bez godine izdanja.

14. As-Suyuti Džalaluddin, Ad-Durr al-manthur fi at-tafsir al-ma'thur, Dar al-fikr, Bejrut, 1414. H./1994.

15. As-Suyuti Džalaluddin, Al-Itqan fi 'ulum al-Qur'an, Tahqiq: Muhammad Abu Fadl Ibrahim, Dar at-turath, Kairo, bez godine izdanja.

16. An-Nuwayri Abu al-Qasim, Šarh Tayyiba an-Našr fi al-qira'at al-'ašr, Tahqiq; 'Abd al-Fattah al-Sayyid Abu-Sunna, izdanje Madžma' al-buhuth al-islamiyya fi al-Qahira, Kairo, 1410. H./1989.

17. As-Suyuti Džalaluddin, Lubab an-nuqul fi asbab an-nuzul (na marginama mushafa u izdanju: Dar ar-Rašid), Damask, bez godine izdanja.

18. Aš-Šawkani Muhammad ibn 'Ali, Fath al-Qadir, Dar al-fikr, Bejrut, 1403. H./1982.

19. At-Tabari Muhammad ibn Džarir, Tafsir at-Tabari (poznato i kao: Džami' albayan 'an ta'wil ay al-Qur'an), priredio Mahmud Šakir, Bejrut, 1405. H./1984.

20. At-Tabari Muhammad ibn Džarir Tarikh at-Tabari, Dar al-kutub al-'ilmiyya, Bejrut, 1407. H./1987.

21. Az-Zarkaši Badruddin Muhammad ibn 'Abdullah, Al-Burhan fi 'ulum al-Qur'an, Al-Maktaba al-'asriyya, priredio Muhammad Abu Fadl Ibrahim, Bejrut, bez godine izdanja. 
22. Az-Zarqani 'Abd al-'Azim, Manahil al-'irfan fi 'ulum al-Qur'an, Dar ihya' alkutub al-'arabiyya, Kairo, bez godine izdanja.

23. Az-Zirikli Khayruddin, Al-A lam, drugo izdanje, Dar al-'ilm li al-malayin, Bejrut, 1997.

24. Az-Zuhayli Muhammad, Ta'rif 'amm bi al-'ulum aš-šar'iyya, Dar Talas, Damask, 1988.

25. Halilović Safvet, Al-Imam Abu-Bakr ar-Razi al-Džassas wa manhadžuhu fi attafsir, Dar as-salam, Kairo, 2001.

26. Halilović Safvet, At-Tafsir bi al-ma'thur - Ahammiyyatuhu wa dawabituhu, Dirasa tatbiqiyya fi sura an-Nisa', Dar al-našr li al-džami'at, Kairo, 1999.

27. Halilović Safvet, Metodologija tumačenja Kur'ana u hanefijskome mezhebu Studija na primjeru Al-Džassasovog tefsira Ahkam al-Qur'an (Propisi Kur'ana), s arapskog preveo dr. Mehmed Kico, Fakultet islamskih nauka, El-Kalem, Sarajevo, 2004.

28. Handžić Mehmed, Uvod u tefsirsku i hadisku nauku, Vrhovno starješinstvo Islamske zajednice u SFRJ, Sarajevo, 1972.

29. Ibn al-Džazari, An-Našr fi al-qira'at al-'ašr, Damask, 1345. H./1926.

30. Ibn al-Džazari, Tabaqat al-qurra', (ili: Gaya an-nihaya fi tabaqat al-qurra'), objavio Gotthelf Begrstrasser, Istanbul, 1935.

31. Ibn-'Ašur Muhammad Fadil, Al-Tafsir wa ridžaluhu, Dar al-Hasanun li al-našr wa at-tawzi', Tunis, 1998.

32. Ibn-'Ašur Muhammad at-Tahir, At-Tahrir wa at-tanwir, Ad-Dar al-tunisiyya li an-našr, Tunis, bez godine izdanja.

33. Ibn-Kathir Abu al-Fida' Isma'il ad-Dimišqi, Tafsir al-Qur'an al-'azim (poznato i kao: Tafsir Ibn-Kathir), Matba'a 'Isa al-Babi al-Halabi, Kairo, bez godine izdanja.

34. Ibn-Hadžar al-'Asqalani, Fath al-Bari bi šarh Sahih al-Bukhari, Dar ar-rayyan li al-turath, Kairo, 1408. H./1987.

35. Ibn-Hadžar al-'Asqalani, Lisan al-mizan, Bejrut, bez godine izdanja.

36. Ibn-Hadžar al-'Asqalani, Tahdhib at-Tahdhib, Dar al-kutub al-islamiyya, kopija indijskog izdanja, 1413. H./1992.

37. Ibn-Hadžar, al-'Asqalani, Taqrib at-Tahdhib, priredio Mustafa 'Abd al-Qadir 'Ata, Dar al-kutub al-'ilmiyya, Bejrut, 1413. H./1992.

38. Ibn-Kathir, Abu al-Fida' Isma'il ad-Dimišqi, Al-Bidaya wa al-nihaya, Bejrut, 1408. H./1988.

39. Ibn-Mudžahid Abu-Bakr, Kitab as-Sab'a fi al-qira'at, priredio Šawqi Dayf, Dar al-ma'arif, Kairo, bez godine izdanja. 
40. Korkut Besim, Prevod značenja Kur'ana, Sarajevo, 1978.

41. Latić Džemaludin, Kur'an - proljeće srca tvog, Novi muallim, br. 18.

42. Muslim Ibn al-Hadždžadž al-Qušayri an-Naysaburi, As-Sahih, paginacija Fu'ad 'Abd al-Baqi, Dar al-kayr, drugo izdanje, Bejrut, 1416. H./1996.

43. Rida Muhammad Rašid, Tafsir al-manar, četvrto izdanje, Kairo, 1380. H./1960.

44. Salih Muhammad Adib, Tafsir an-nusus, Al-Maktab al-islami, četvrto izdanje, Bejrut, 1413. H./1993.

45. Sazkin Fu'ad, Tarikh at-turath al-'arabi, Rijad, 1404. H./1983.

46. Subhi as-Salih, Mabahith fi 'ulum al-Qur'an, Dar al-'ilm li al-malayin, osamnaesto izdanje, Bejrut, 1990. 
PROF. DR. SAFVET HALILOVIĆ, P.H.D.

\section{QIRA'ATS AND THEIR SIGNIFICANCE IN THE TAFSEER SCIENCE}

\section{SUMMARY}

One of the specific qualities of the Holy Qur'an is the possibility to pronounce certain words in various ways, according to the Revelation. There is a specific scientific discipline in Islamic tradition related to this phenomenon which is called Qira'ats ('ilm al-qira'at). It is a science that deals with the study of pronunciation of the words in the Holy Qur'an, which is transmitted from Allah's Messenger, peace and blessings be upon him. There are authorities in that scientific area who have set up precise criteria and wrote significant literature, with objective to preserve content authenticity of the Holy Qur'an.

After brief historical reflection on origins of the Qira' at science with mention of its main representatives and their science methodology, this paper has elaborated the significance and position of Qira'ats in the Tafseer science. The Tafseer science deals primarily with the study of the Holy Qur'an, with objective to discover those meanings which the Divine Creator intended for human kind to understand. In that aspect, Qira'ats are a very important part of the Tafseer science, especially if we have in mind that differences in pronouncing certain words in the Holy Qur'an can result in different norms and meaning.

This paper highlights the enormous determination which the commentators of the Holy Qur'an have invested in their Tafseer works, dealing with the Qira'at analysis and determining their authenticity ( ithbat tawatur al-qira'at), along with proper orientation of every valid Qira'at and detail explanation of consisted meanings.

This paper points out that the possibility to pronounce certain words of the Holy Qur'an in various ways, testifies of greatness and universality of Qur'an's contents. Qur'an is God's Speech; its meanings are inexhaustible and cannot be reduced to some time limited dimension of human comprehension. 
Key words: Qira'ats, Tafseer, Ibn Al-Jazari, Al-Ghassas, seven Qira'ats, authentic/ mutawatir Qira'ats, shaz/ unauthentic Qira'ats 
الأستاذ الدكتور صفوت خليلوفيتش

\section{القراءات وأهميتها في علم التفسير}

\section{خلاصة البحث}

من خصائص النص القرآي احتمال أن بعض كلمات للقرآن الكريم، وفقاً للوحي نفسه، يمكن أن تنطق بأساليب كثيرة. في ذلك السياق هناك في التقاليد الاسلامية فن علمي خاص يدعى القراءات (علم القراءات)، وهو العلم الذي يهتم بدراسة نطق الكلمات القرآنية، المنقول

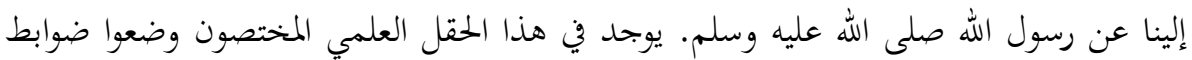
دقيقة وألفوا المؤلفات العظيمة، كل ذلك بهدف الحفاظ على صحة النص القرآين. هذا البحث، وبعد استعراض تاريخي موجز لظهور علم القراءات، حيث تم ذكر ممثليها

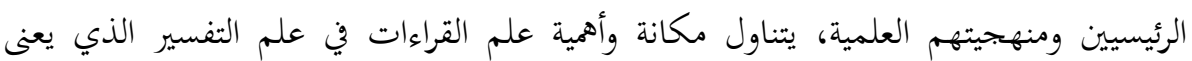
أساساً بدراسة القرآن الكريم بهدف اكتشاف المعنى الذي قصد الخالق أن يقوله للناس. في هذا

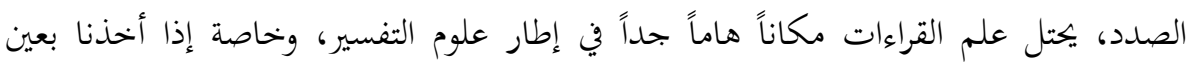
الاعتبار أن النطق المختلف لبعض الكلمات القرآنية قد يؤدي إلى حكم ومعنى مختلف للنص القرآي.

يشير البحث إلى الجهود الضخمة التي بذها المفسرون للقرآن الكريم في كتب التفسير من خلال تحليل القراءات وإثبات تواترها، وخصوصاً من خلال التوجيه السليم لكل قراءة صحيحة والشرح المفصل للمعنى الذي يتضمنه.

هذا البحث، من جملة الأمور، يشير إلى أن القدرة على نطق بعض الكلمات في القرآن

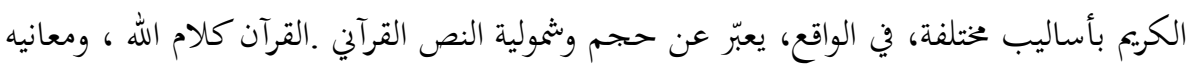

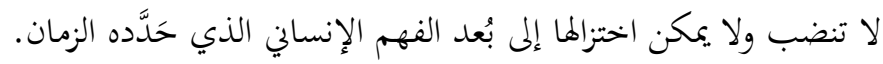
في كتابة البحث هذا استخدمت المنهجية التاريخية التحليلية، على الأغلب. الكلمات الرئيسة: القراءات، التفسير، ابن الجزري، الجصاص، القراءات السبع، القراءات المتواترة، القراءات الشاذة 